\title{
Nitrification in Freshwater Sediments as Influenced by Insect Larvae: Quantification by Microsensors and Fluorescence in Situ Hybridization
}

\author{
D. Altmann, P. Stief, R. Amann and D. de Beer \\ Max-Planck-Institute for Marine Microbiology, D-28359 Bremen, Germany \\ Received: 6 June 2003 / Accepted: 9 September 2003 / Online publication: 27 April 2004
}

\begin{abstract}
Sediment-reworking macrofauna can stimulate nitrification by increasing the $\mathrm{O}_{2}$ penetration into sediments or it can reduce nitrification by grazing on nitrifying bacteria. We investigated the influence of Chironomus riparius larvae (Insecta: Diptera) on the in situ activity, abundance, and distribution of $\mathrm{NH}_{4}^{+}$-oxidizing (AOB) and $\mathrm{NO}_{2}^{-}$-oxidizing bacteria (NOB) in two freshwater sediments with microsensors and fluorescence in situ hybridization. In organic-poor sediment, nitrification activity was reduced by the presence of $C$. riparius larvae, whereas no such effect was detected in organic-rich sediment. We explain this difference with the variable larval burrowing and grazing behavior in the two sediment types: In organic-poor sediment larval activities were intense and evenly distributed across the whole sediment surface, whereas in organic-rich sediment larval activities were locally restricted to the microenvironment of animal burrows. Surprisingly, the animals did not cause any significant change of the abundance of $\mathrm{AOB}$ and NOB. This implies that the observed reduction of nitrification activity was not density-regulated, but rather was due to the lowered metabolic activity of the nitrifiers. Partial digestion and redeposition of particle-associated bacteria by $C$. riparius larvae are believed to have caused this loss of metabolic activity.
\end{abstract}

\section{Introduction}

Nitrification, the microbially mediated oxidation of $\mathrm{NH}_{4}^{+}$ to $\mathrm{NO}_{3}^{-}$, plays a central role in the $\mathrm{N}$-cycle of aquatic environments, since it links the mineralization of organic matter (formation of $\mathrm{NH}_{4}^{+}$) to the recycling of $\mathrm{N}$ to the

Correspondence to: P. Stief; E-mail: pstief@mpi-bremen.de atmosphere (denitrification of $\mathrm{NO}_{3}^{-}$). Especially with respect to the growing eutrophication of aquatic environments this link is indispensable for the elimination of $\mathrm{N}$ from polluted ecosystems [12]. Sediment bioturbation and bioirrigation increase the colonizable sediment/water interface area and the substrate availability for benthic nitrifiers, respectively $[3,14,21,37]$. On the other hand, grazing by deposit-feeding invertebrates can also significantly reduce the abundance or the metabolic activity of particle-associated bacteria $[13,26,29]$. Depth-specific behavior of benthic macrofauna, i.e., grazing at the sediment surface, vertical particle relocation, and ventilation of deeper layers, can simultaneously stimulate bacterial activity and reduce microbial biomass in different layers of the same sediment [34].

In situ identification and enumeration of nitrifying bacteria in bioturbated freshwater sediments have been ignored so far, even though a qualitative and quantitative analysis might reveal the mechanisms of macrofaunal influence on nitrification. The presence of benthic macrofauna may affect nitrifiers more severely than other bacterial groups because (i) their activity is strongly coupled to the presence of $\mathrm{O}_{2}$ and (ii) they are particularly poor competitors for both $\mathrm{O}_{2}$ and $\mathrm{NH}_{4}^{+}$ [27]. Therefore, (i) macrofaunal ventilation of sediment with $\mathrm{O}_{2}$ may favor nitrifiers more than other bacteria and (ii) macrofaunal grazing on particle-associated microorganisms may suppress nitrifiers more than other bacteria. The method of choice to specifically quantify nitrifying populations is the fluorescence in situ hybridization (FISH) [8], a cultivation-independent technique that has been applied successfully in various aquatic environments $[15,25]$. In addition, the combination of FISH with microsensors has proven a powerful tool to investigate the in situ structure and function of nitrifying communities in biofilms $[9,32]$ and in freshwater sediment [1]. 
With our laboratory experiments we aimed at evaluating the influence of $C$. riparius larvae on the in situ activity, composition, and distribution of $\mathrm{NH}_{4}^{+}$- and $\mathrm{NO}_{2}^{-}$-oxidizing populations. Based on the results of a previous study we hypothesized that grazing by $C$. riparius decreases the nitrification activity in the top layer of the sediment and that larval ventilation increases the nitrification activity in deeper layers [34]. We combined the use of microsensors and FISH to determine if the activity changes were caused by spatially coincident changes of $\mathrm{AOB}$ and $\mathrm{NOB}$ abundance.

\section{Materials and Methods}

Sediment Sampling and Incubation. Surface sediment $(0-5 \mathrm{~cm})$ was collected from two field sites differing in grain size and organic content: (i) Sandy sediment (mean grain size: $200 \mu \mathrm{m}$ ) was sampled from a small lowland stream, called Rittrumer Mühlenbach, that is located near Wildeshausen (northern Germany). The sediment had a low organic content [weight loss on combustion: $2.5 \pm 0.3 \%$ (mean \pm s.d., $n=20$ )] and was only sparsely inhabited by chironomids of unidentified species, (ii) Silty sediment (mean grain size: $<100 \mu \mathrm{m}$ ) was collected from Millinger Landwehr, a man-made brook in the flood plains of the Lower River Rhine near Rees (northwest Germany). The organic content of this sediment was $12.7 \pm 2.2 \%$ (mean \pm s.d., $n=20$ ) and contained moderate densities of Chironomus spp. The sediments were sieved (mesh size: $1 \mathrm{~mm}$ ) to remove macrofauna and large detritus, filled into Perspex cylinders (diameter $9 \mathrm{~cm}$, height $13 \mathrm{~cm}$ ), and allowed to settle overnight. Replicate cylinders were preincubated in the dark at $15^{\circ} \mathrm{C}$ in opaque basins containing $24 \mathrm{~L}$ of aerated streamwater until rates of $\mathrm{NH}_{4}^{+}$uptake by the sediment remained stable over time [35]. $\mathrm{NO}_{3}^{-}$and $\mathrm{NH}_{4}^{+}$concentrations in the water were kept constant at 500 and $50 \mu \mathrm{mol} \mathrm{L}{ }^{-1}$, respectively, by repeated addition of aliquots from $\mathrm{NaNO}_{3}$ and $\mathrm{NH}_{4} \mathrm{Cl}$ stock solutions. After preincubation, C. riparius larvae (larval stage IV, mean body length $1 \mathrm{~cm}$ ), taken from a laboratory-bred population, were introduced into the sediment cylinders at an abundance of 1 individual $\mathrm{cm}^{-2}$ [34]. Cylinders were checked daily for dead and emerged larvae that were replaced by new larvae.

Six sediment cylinders each were incubated with organic-poor, sandy sediment and organic-rich, silty sediment. Three sediment cylinders of each experimental run served as controls, i.e., they did not receive larvae, while the remaining cylinders served as animal treatments. After 14 days of incubation in the dark at $15^{\circ} \mathrm{C}$, microsensor measurements and fixation of sediment samples for FISH were completed within 3 days.
Microsensor Measurements. Microsensors for $\mathrm{O}_{2}$ [28], $\mathrm{NO}_{3}^{-}$, and $\mathrm{NH}_{4}^{+}[6,7]$ were prepared, calibrated, and operated in a measuring setup as previously described [35]. In the organic-poor sediment measurements were performed at random positions of the sediment, whereas in the organic-rich sediment only positions between animal burrows were chosen. Profiles were recorded down to a depth of $10 \mathrm{~mm}$, which corresponded to the maximum observed burrowing depth in our sediments. Local volumetric conversion rates were calculated as the second derivative of the concentration profiles [5]. Within the resulting conversion rate profile, five consecutive data points were averaged to obtain a spatial resolution of $1 \mathrm{~mm}$. This was done (i) to more clearly arrange data, (ii) to reduce noise resulting from the calculation procedure, and (iii) to approximate the spatial resolution of the FISH.

Overall nitrification was quantified by integrating the local $\mathrm{NO}_{3}^{-}$production rates over the depth of $\mathrm{O}_{2}$ penetration. $\mathrm{NO}_{3}^{-}$rather than $\mathrm{NH}_{4}^{+}$turnover was chosen as a proxy of nitrification because the latter is less indicative of nitrification, i.e., in the oxic layer $\mathrm{NH}_{4}^{+}$can be formed by mineralization, consumed by nitrification and heterotrophic uptake, and sorbed to particle surfaces. The local $\mathrm{NO}_{3}^{-}$production rates within the oxic layer were summed up, and the obtained sum was multiplied with the thickness of the single conversion layers to give the depth-integrated $\mathrm{NO}_{3}^{-}$production rate $\left(J_{\mathrm{NO} 3}\right.$ nitrif $)$. In the same fashion the depth-integrated $\mathrm{O}_{2}$ consumption rate $\left(J_{\mathrm{O} 2}\right.$ nitrif $)$ within the nitrification layer was calculated. Based on the stoichiometry of nitrification [27] the shares of autotrophic and heterotrophic $\mathrm{O}_{2}$ consumption ( $J_{\mathrm{O} 2}$ auto and $J_{\mathrm{O} 2}$ hetero, respectively) from $J_{\mathrm{O} 2}$ nitrif were estimated:

$$
\begin{gathered}
J_{\mathrm{O} 2 \text { auto }}=2 J_{\mathrm{NO} 3} \text { nitrif } \\
J_{\mathrm{O} 2 \text { hetero }}=J_{\mathrm{O} 2 \text { nitrif }}-J_{\mathrm{O} 2 \text { auto }}
\end{gathered}
$$

Total Flux Measurements. In supplement of the depth-integrated rates within the nitrification layer the total sediment/water solute exchange (i.e., the total flux) was determined in cylinders loaded with organic-rich sediment. The total flux comprises the diffusive and advective solute transport between sediment and water plus the solute conversions taking place in the sediment. The overlying water was aerated and nominally adjusted to $100 \mu \mathrm{mol} \mathrm{L}^{-1} \mathrm{NH}_{4}^{+}$and $500 \mu \mathrm{mol} \mathrm{L}-1 \mathrm{NO}_{3}^{-}$. Apparent $\mathrm{NH}_{4}^{+}$and $\mathrm{NO}_{3}^{-}$concentrations in the overlying water were analyzed at $t_{0}=0 \mathrm{~h}$ and $t_{1}=4 \mathrm{~h}$ using photometric test kits by Merck (Germany). Linearity of the concentration changes during the first $4 \mathrm{~h}$ of the incubation was ascertained in one cylinder by sampling the overlying 

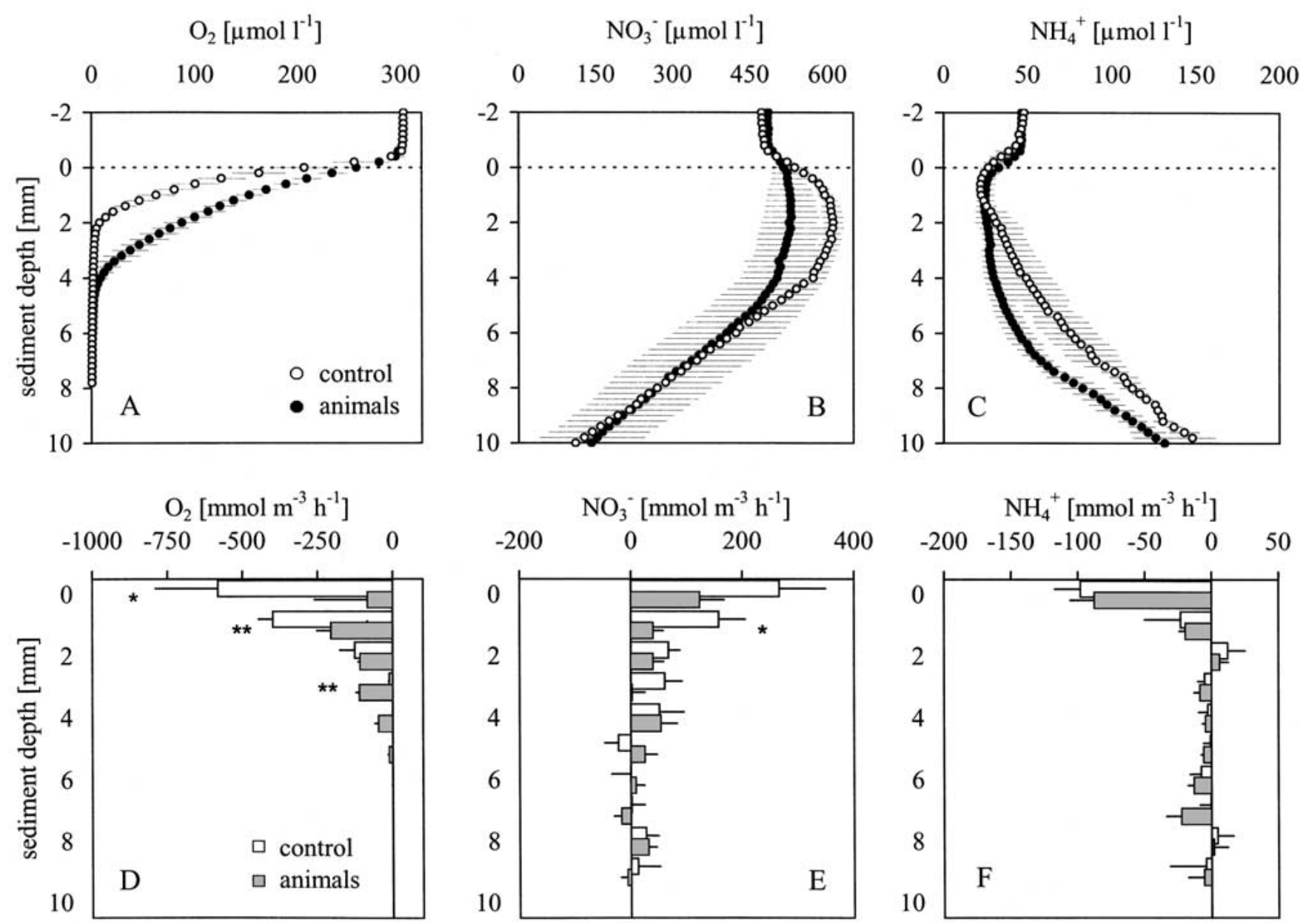

Figure 1. Vertical concentration profiles (A-C) and solute conversion rates (D-F) in organic-poor sediment incubated with and without C. riparius larvae. Dotted line indicates sediment surface. Positive values indicate production; negative values indicate consumption (D-F). Means and standard deviation of three replicate sediment cylinders are given. Welch-corrected $t$-tests between animal and control treatments revealed significant differences at $P<0.05\left(^{*}\right), P<0.01\left(^{* *}\right)$, and $P<0.001\left(^{* * *}\right)$.

water every hour. Total fluxes $\left(J_{\text {total }}\right)$ of $\mathrm{NH}_{4}^{+}$and $\mathrm{NO}_{3}^{-}$ were calculated as:

$$
J_{\text {total }}=(\Delta C \times V) /(\Delta t * A)
$$

where $\Delta C$ is the concentration change over the time interval $\Delta t, V$ is the volume of the overlying water, and $A$ is the cross-section area of the sediment surface.

FISH and Total Cell Counts. One sediment core (diameter $2.5 \mathrm{~cm}$ ) was taken from each sediment cylinder and sectioned horizontally into 2-mm-thick slices down to a depth of $10 \mathrm{~mm}$. Sediment slices were fixed with paraformaldehyde [15] and diluted 30-fold in a 1:1 mixture of phosphate-buffered saline (composed of $130 \mathrm{mmol} \mathrm{L}^{-1} \mathrm{NaCl}, 3 \mathrm{mmol} \mathrm{L}{ }^{-1} \mathrm{NaH}_{2} \mathrm{PO}_{4}$ and $7 \mathrm{mmol}$ $\mathrm{L}^{-1} \mathrm{Na}_{2} \mathrm{HPO}_{4}, \mathrm{pH} 7.2$ ) and $96 \%$ ethanol. Sediment suspensions were sonicated with a type UW70 probe $(3 \times$ $60 \mathrm{~s}, 20 \%$ pulse, $109 \mu \mathrm{m}$ amplitude, Sonopuls HD70; Bandelin, Germany). Aliquots of $20-30 \mu \mathrm{L}$ of a 10 -fold dilution of the sonicated samples were immobilized on gelatin-coated microscopic slides. For FISH oligonucleotide probes specific for (i) $\mathrm{NH}_{4}^{+}$-oxidizing $\beta$-Proteobacteria (NSO1225, [19]) and (ii) for the $\mathrm{NO}_{2}^{-}$-oxidizing genera Nitrobacter (NIT3, [38]) and Nitrospira (NTSPA662, [4]) were used. Probes NIT3 and NTSPA662 were used with equimolar amounts of competitor oligonucleotides as indicated in the references. Correction for unspecific binding was achieved by subtracting cell numbers hybridized with control probe NON338 [16] from the FISH counts. All probes were purchased labeled with the fluorescent dye Cy3 (Hybaid Interactiva, Germany). FISH and counterstaining of all cells with $4^{\prime}$,6-diamino-2-phenylindole (DAPI; $0.5 \mu \mathrm{g}$ $\mathrm{mL}^{-1}$ ) were performed according to published protocols [25]. Counting was adapted to the low numbers of FISHpositive cells and their uneven distribution in the aliquots as described in [1]. Total cell counts were determined separately by DAPI-staining of sonicated and diluted 


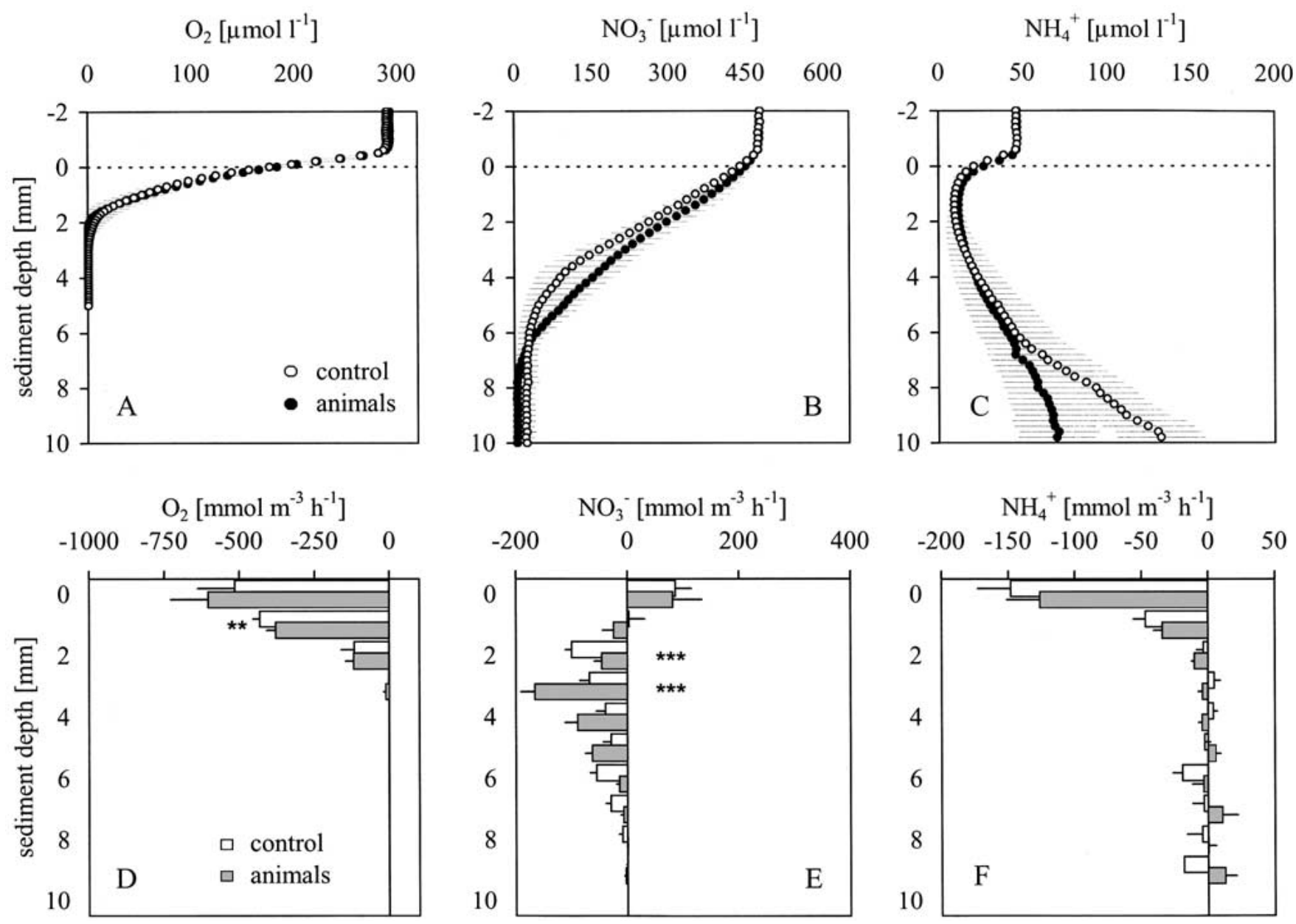

Figure 2. Vertical concentration profiles $(\mathrm{A}-\mathrm{C})$ and solute conversion rates $(\mathrm{D}-\mathrm{F})$ in organic-rich sediment incubated with and without $C$. riparius larvae. See Fig. 1 for further details.

sediment samples on black membrane polycarbonate filters (pore size, $0.2 \mu \mathrm{m}$; Osmonics, USA). The absolute numbers of FISH-positive cells were calculated for each probe using the relative FISH-positive counts (as percentage of DAPI-stained cells) and the total cell counts.

\section{Results}

Larval Behavior. In both sediments the larvae of $C$. riparius buried quickly into the sediment. However, larval burrowing and feeding behavior was different in the two investigated sediment types. In the organic-poor sediment, larvae reworked the top $5 \mathrm{~mm}$ and made the surface look fluffier than in the larvae-free controls. Fecal pellets (diameter $300 \mu \mathrm{m}$ ) were evenly distributed across the whole sediment surface and were also found in the subsurface layer down to a depth of $\sim 5 \mathrm{~mm}$. In the organic-rich sediment, however, most of the larvae constructed permanent burrows that were actively aerated by undulating body movements. Particle redistribution was less intense than in the organic-poor sediment, and thus the fecal pellets were mainly deposited around the burrow outlets.

Larval Effects on Nitrification Activity. $\quad$ After the 2week incubation with $C$. riparius larvae, steady-state profiles of $\mathrm{O}_{2}, \mathrm{NH}_{4}^{+}$, and $\mathrm{NO}_{3}^{-}$were recorded. $\mathrm{O}_{2}$ penetrated $1.8 \mathrm{~mm}$ into the organic-poor control sediment, while the presence of the larvae enhanced $\mathrm{O}_{2}$ penetration to $3.8 \mathrm{~mm}$ (Fig. 1A). Local $\mathrm{O}_{2}$ consumption rates were significantly reduced in the presence of animals (Fig. 1D). $\mathrm{NO}_{3}^{-}$was net produced down to a sediment depth of 4-5 $\mathrm{mm}$ in the organic-poor sediment in both the animal and control treatments (Fig. 1E), but $\mathrm{NO}_{3}^{-}$ production rates were lower in the presence of larvae. Superficial $\mathrm{NO}_{3}^{-}$production exceeded $\mathrm{NO}_{3}^{-}$consumption below the oxic layer, rendering the organic-poor sediment a source for $\mathrm{NO}_{3}^{-}$to the overlying water. This was true for both the control and the animal treatments despite the lower $\mathrm{NO}_{3}^{-}$production rates in the latter 


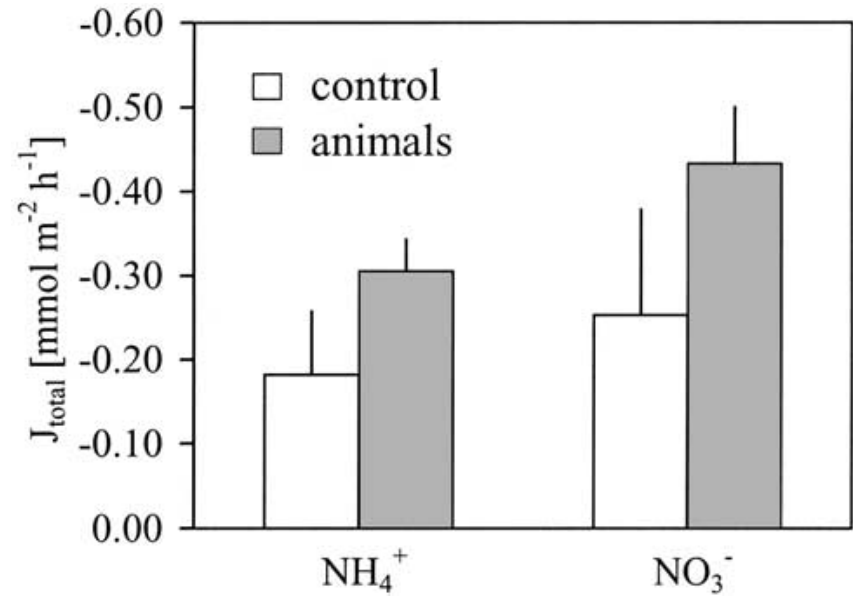

Figure 3. Total fluxes of $\mathrm{NO}_{3}^{-}$and $\mathrm{NH}_{4}^{+}$measured in organic-rich sediment incubated with and without $C$. riparius larvae. Negative values indicate solute uptake by the sediment. Means and standard deviation of three replicate sediment cylinders are given. Welchcorrected $t$-tests between animal and control treatments did not reveal significant differences.

treatment. Net $\mathrm{NH}_{4}^{+}$consumption was to the uppermost $2 \mathrm{~mm}$ of the sediment (Fig. 1F) and was not influenced by the larvae.

In the organic-rich sediment, microprofiles were recorded only in between larval burrows. Here, the animalrelated increase of $\mathrm{O}_{2}$ penetration was only from 1.4 to $1.8 \mathrm{~mm}$ (Fig. 2A), and no clear effect on $\mathrm{O}_{2}$ consumption was observed (Fig. 2D). The highest $\mathrm{NO}_{3}^{-}$production and $\mathrm{NH}_{4}^{+}$consumption rates were measured in the 0 $1 \mathrm{~mm}$ layer (Figs. 2E, F), but were not significantly influenced by the presence of larvae. In contrast to the organic-poor sediment, consumption of $\mathrm{NO}_{3}^{-}$below a sediment depth of $1 \mathrm{~mm}$ exceeded the superficial production of $\mathrm{NO}_{3}^{-}$. Thus, the organic-rich sediment acted as a sink for $\mathrm{NO}_{3}^{-}$from the overlying water. In the presence of larvae the maxima of $\mathrm{NO}_{3}^{-}$consumption were shifted downward and, moreover, exceeded those of the control treatments significantly (Fig. 2E).

The total flux measurements carried out in the organic-rich sediment revealed an increased net uptake of $\mathrm{NO}_{3}^{-}$and $\mathrm{NH}_{4}^{+}$by the animal-inhabited sediment (Fig. 3).
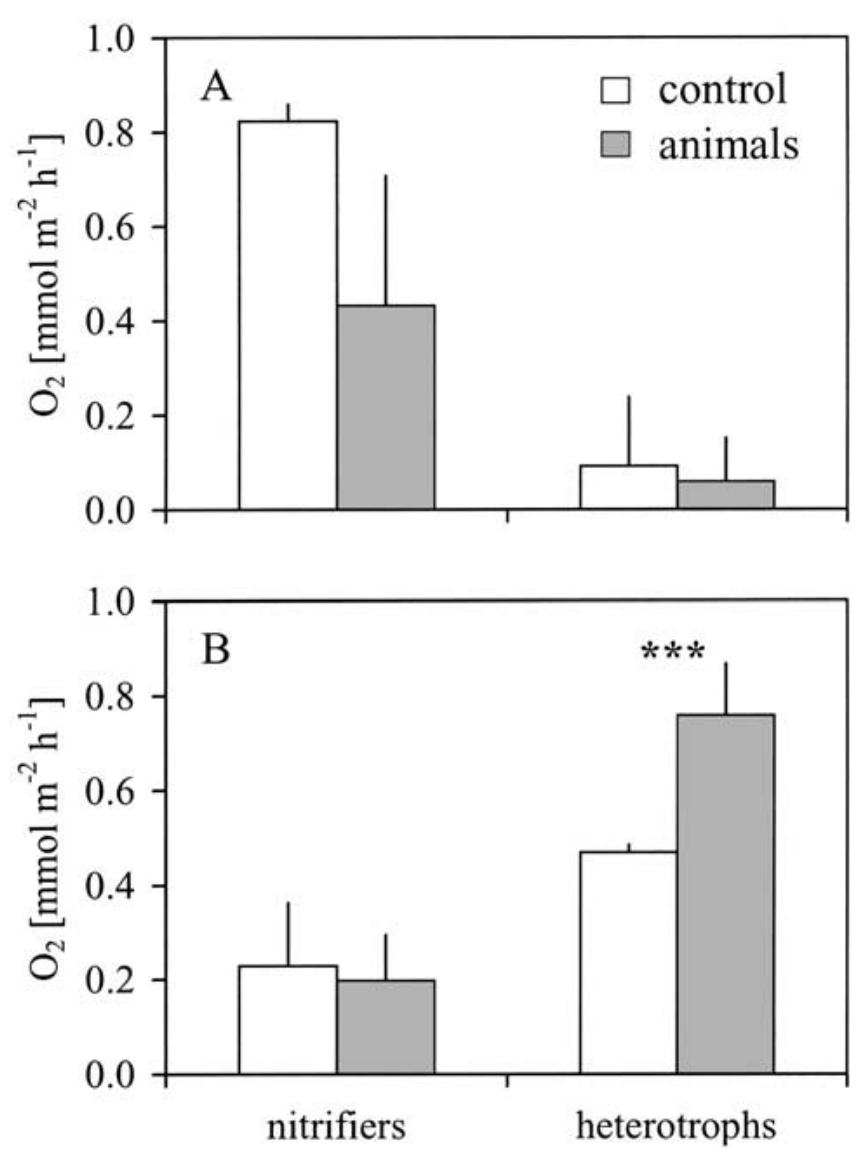

Figure 4. $\mathrm{O}_{2}$ consumption by nitrifiers and heterotrophs in organic-poor (A) and organic-rich sediment (B) incubated with and without $C$. riparius larvae. Means and standard deviation of three replicate sediment cylinders are given. Welch-corrected $t$-tests between animal and control treatments revealed one significant difference at $\left.P<0.001{ }^{* * *}\right)$.

\section{Larval Effects on Autotrophic and Heterotrophic} Activity. For the nitrification layer microsensor data were used to calculate the partitioning between the $\mathrm{O}_{2}$ consumed by autotrophic nitrification and heterotrophic metabolism ( $J_{\mathrm{O} 2}$ auto and $J_{\mathrm{O} 2}$ hetero, respectively). The depth-integrated conversion rates $J_{\mathrm{O} 2}$ nitrif and $J_{\mathrm{NO} 3}$ nitrif used for these calculations are listed in Table 1. In the organic-poor sediment $\mathrm{O}_{2}$ was mainly consumed by nitrification (Fig. 4A), whereas in the organic-rich sedi-

Table 1. Depth-integrated conversion rates of $\mathrm{O}_{2}, \mathrm{NO}_{3}^{-}$, and $\mathrm{NH}_{4}^{+}\left(\mathrm{mmol} \mathrm{m}^{-2} \mathrm{~h}^{-1}\right)$ within the nitrification layer of organic-poor and organic-rich sediment either devoid or inhabited by $C$. riparius larvae

\begin{tabular}{lrrrr}
\hline & \multicolumn{3}{c}{ Organic-poor } & \multicolumn{2}{c}{ Organic-rich } \\
\cline { 2 - 5 } & \multicolumn{1}{c}{ Control } & \multicolumn{1}{c}{ Animals } & \multicolumn{1}{c}{ Control } \\
\hline $\mathrm{O}_{2}$ & $-0.915 \pm 0.236$ & $-0.489 \pm 0.183$ & $-0.790 \pm 0.120$ & $-1.012 \pm 0.212$ \\
$\mathrm{NO}_{3}^{-}$ & $0.404 \pm 0.027$ & $0.199 \pm 0.121$ & $0.105 \pm 0.098$ & $0.102 \pm 0.064$ \\
$\mathrm{NH}_{4}^{+}$ & $-0.124 \pm 0.053$ & $-0.108 \pm 0.025$ & $-0.184 \pm 0.033$ & $-0.161 \pm 0.020$ \\
\hline
\end{tabular}

Mean rates \pm s.d. of three replicate cores are given. Negative values indicate consumption of $\mathrm{O}_{2}$ and $\mathrm{NH}_{4}^{+}$; positive values indicate production of $\mathrm{NO}_{3}^{-}$. 

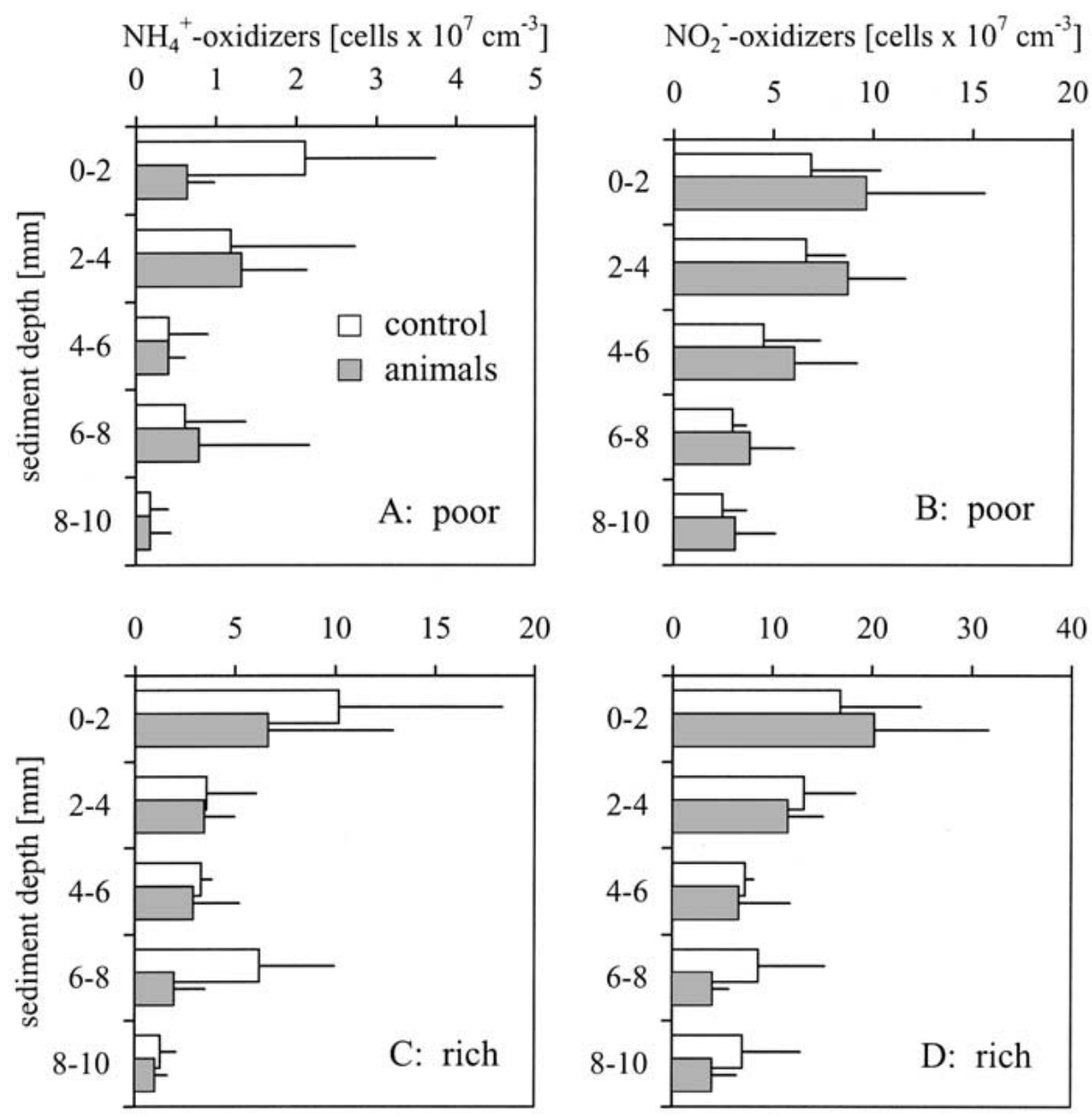

Figure 5. Absolute abundances of $\mathrm{NH}_{4}^{+}$-oxidizing $\beta$-proteobacteria and $\mathrm{NO}_{2}^{-}$-oxidizing Nitrospira sp. in organic-poor (A, B) and organic-rich sediment $(C, D)$ incubated with and without $C$. riparius larvae. Means and standard deviation of three replicate sediment cylinders are given. Welchcorrected $t$-tests between animal and control treatments did not reveal significant differences.

ment heterotrophic $\mathrm{O}_{2}$ consumption was of greater importance than nitrification (Fig. 4B). In the organicpoor sediment the presence of the animals caused a decrease in $\mathrm{O}_{2}$ consumption by nitrification, but not by heterotrophic metabolism (Fig. 4A). In the organic-rich sediment, however, the heterotrophic $\mathrm{O}_{2}$ uptake was significantly enhanced in the presence of larvae, while $\mathrm{O}_{2}$ consumption by nitrification remained unchanged (Fig. 4B).

Identity and Distribution of Nitrifiers. In the organic-poor sediment total numbers of bacteria were evenly distributed over the sampled sediment depth and were as high as $3.2-3.6 \times 10^{9} \mathrm{~cm}^{-3}$ in both control and animal treatments. In the organic-rich sediment total numbers of bacteria varied as much as from 4.8 to $12.2 \times$ $10^{9} \mathrm{~cm}^{-3}$, but this was due to in-core variability rather than to the activity of larvae. In both sediment types the maximum abundances of $\mathrm{AOB}$ and $\mathrm{NOB}$ coincided spatially with the high conversion rates of $\mathrm{O}_{2}, \mathrm{NH}_{4}^{+}$, and $\mathrm{NO}_{3}^{-}$in the $0-2 \mathrm{~mm}$ layer (Fig. 5A-D). In this layer the $\mathrm{NH}_{4}^{+}$-oxidizing $\beta$-proteobacteria, as determined with probe NSO1225, accounted for 0.6 and $1.2 \%$ of all bac- terial cells in the organic-poor and organic-rich sediment, respectively. $\mathrm{NO}_{2}^{-}$-oxidizing bacteria of the genus Nitrospira, as detected with probe NTSPA662, accounted for $\sim 2 \%$ of all bacterial cells in both sediment types. The abundances of Nitrospira sp. remained relatively high even with increasing depth, making up at least $1.0 \%$ of all bacterial cells even in the bottommost sediment layer. Nitrobacter sp., the most commonly isolated NOB, was not detected with probe NIT3 in any of the sediment treatments. In both sediments the presence of the chironomids had no significant influence on the abundances and the distribution patterns of $\mathrm{AOB}$ and NOB (Fig. 5A-D).

\section{Discussion}

We applied microsensors in combination with FISH to evaluate the influence of $C$. riparius larvae on both the activity and the distribution of the $\mathrm{NH}_{4}^{+}$- and $\mathrm{NO}_{2}^{-}$oxidizing bacteria ( $\mathrm{AOB}$ and $\mathrm{NOB}$ ) in sediments. In a previous study larval deposit-feeding decreased the nitrification activity at the sediment surface, whereas in deeper layers larval ventilation increased the nitrification 
activity [34]. This depth-specific effect of macrofauna was ascribed to changes in the abundance of nitrifiers (i.e., reduced abundance due to grazing losses, increased abundance due to additional supply with $\mathrm{O}_{2}$ and $\mathrm{NH}_{4}^{+}$). In our study the presence of larvae reduced the nitrification activity in the top layer of organic-poor, but not organic-rich, sediment. However, the abundance of neither AOB nor NOB was affected by the presence of animals in any of the two sediments.

Larval Behavior. Sediment reworking and feeding by C. riparius larvae were different in the two sediment types, with evenly distributed activities in the organicpoor and locally restricted activities in the organic-rich sediment. This differential behavior was due to the absence (organic-poor sediment) or presence (organic-rich sediment) of permanent animal burrows. In organicpoor sediment the larvae may be compelled to live without burrows because of the incessant search for food or the inability to construct stable burrows in the sandy substrate. In contrast, the larval food requirements may be met in the immediate burrow neighborhood of the organic-rich sediment, in which burrow stabilization may also be facilitated because of the smaller sediment grains. The differential behavior of chironomids in the two sediment types has major implications for the interpretation of our microsensor data. In the organic-poor sediment the vertical profiles recorded at random positions of the sediment surface can be taken as representative of the average distribution of solutes (see also [34]) because of the larvally induced homogenization of the sediment surface. In contrast, in the organic-rich sediment the microsensor technique revealed only the animal impact on the bulk sediment in between animal burrows, while the additional $\mathrm{N}$ conversions inside the burrows were excluded. Therefore, the overall effect of the chironomid larvae on total benthic $\mathrm{N}$ conversions was more accurately represented by the total fluxes as determined with whole core incubations (see also [2, 17]). The latter data demonstrated that $C$. riparius larvae did not change the role of the organic-rich sediment as a sink for $\mathrm{NO}_{3}^{-}$ coming from the overlying water.

Larval Effects on Nitrification and Heterotrophic Metabolism. In several previous studies a stimulation of benthic nitrification by chironomid larvae has been demonstrated $[18,22,23,36]$. Stimulation of this $\mathrm{O}_{2-}$ dependent process was mostly ascribed to the increased $\mathrm{O}_{2}$ penetration due to ventilation, the extended sediment/water interface area, and the release of $\mathrm{NH}_{4}^{+}$by the animals. However, in our experiment, the animals lowered the overall nitrification rates (i.e., the depth-integrated $\mathrm{NO}_{3}^{-}$production rates) in organic-poor sediment despite a substantially improved $\mathrm{O}_{2}$ supply. Because the abundance of nitrifiers remained almost unchanged in the presence of animals, this decrease has to be interpreted as a reduction of the metabolic activity of single cells or, what is more likely, a decrease of the active proportion of the nitrifying population. We assume that larval ingestion and digestion of sediment particles and the subsequent redeposition of fecal pellets into the sediment reduced the overall metabolic activity in the surface layer of the organic-poor sediment. The reduction of activity and abundance of particle-associated bacteria by deposit-feeding invertebrates has been also shown in other studies $[10,13,26,29]$. The metabolic recovery of different groups of bacteria that survive the gut passage probably occurs at different rates. Nitrifiers, for example, are poor competitors with heterotrophic bacteria because of their slow growth [27] and comparably high $K_{m}$ values for $\mathrm{O}_{2}$ [33]. Thus, nitrifiers may recover more slowly from the adverse gut passage than do heterotrophic bacteria. Indeed, in the surface layer of the organic-poor sediment $\mathrm{O}_{2}$ consumption due to nitrification was reduced in the presence of the larvae, whereas heterotrophic $\mathrm{O}_{2}$ consumption remained unchanged.

It has to be stressed here that the reduced net nitrification could in principle be due to increased $\mathrm{NO}_{3}^{-}$ consumption that simultaneously took place in the oxic sediment layer. For instance, $\mathrm{NO}_{3}^{-}$might have been assimilated by microalgae, but this possibility was excluded in our experiments because they were run in complete darkness. Alternatively, $\mathrm{NO}_{3}^{-}$might have been consumed dissimilatorily in anoxic microniches surrounding organic particles [30], but our $\mathrm{O}_{2}$ microprofiles within the oxic layer were never interrupted by hypoxic or anoxic depressions. In addition, since microsensors are characterized by their superior spatial resolution, the obtained in situ rates are representative of one defined microenvironment (e.g., a particular sediment layer) and not a blur of several functionally different compartments. Therefore, the decreasing $\mathrm{NO}_{3}^{-}$production in the oxic sediment layer was most likely due to the decreasing activity of nitrifiers. Microsensor measurements (e.g., $\mathrm{O}_{2}$ measurements) on single fecal pellets could lend support to the idea of the lowered metabolic activity of particleassociated bacteria that are freshly redeposited into the sediment. Moreover, $\mathrm{NH}_{4}^{+}$and $\mathrm{O}_{3}^{-}$microsensor measurements could provide evidence for the lowered nitrification activity of these particles that may in return lower the overall sedimentary nitrification activity.

In the sediment between the burrows that pervaded the organic-rich sediment, the microsensor approach did not reveal a significant, animal-induced effect on net nitrification. However, the animal-inhabited sediment was characterized by a higher net uptake of both $\mathrm{NO}_{3}^{-}$ and $\mathrm{NH}_{4}^{+}$as revealed by the total fluxes measured in whole core incubations. This elevated nutrient uptake was probably due to the great number of permanent burrows that displayed a high microbial activity, as has 
also been shown by other authors [14, 37, 38]. Although the burrows enhanced the uptake of $\mathrm{NH}_{4}^{+}$, their role as additional sites of nitrification remains unclear because at the same time no net production of $\mathrm{NO}_{3}^{-}$occurred. The burrows even acted as additional sinks for $\mathrm{NO}_{3}^{-}$, probably because of dissimilatory reduction of $\mathrm{NO}_{3}^{-}$in the burrow walls. Moreover, net $\mathrm{NH}_{4}^{+}$uptake is a poor indicator of nitrification activity, since $\mathrm{NH}_{4}^{+}$may also quantitatively adsorb to particle surfaces or even be produced simultaneously by mineralization. The role of $C$. riparius burrows as important sites of microbial $\mathrm{N}$ conversions should be evaluated in future studies by microsensor measurements directly inside these sediment structures. In a first approach, the uncovering of the $\mathrm{O}_{2}$ dynamics within burrows could hint to processes that are likely to occur (i.e., aerobic vs anaerobic pathways).

Even though the microsensor approach did not reveal an animal effect on net nitrification in the organicrich sediment, the heterotrophic $\mathrm{O}_{2}$ consumption was significantly increased by the animals in the sediment between the burrows. This could be a consequence of the fertilization of heterotrophic microbes, but not nitrifiers, with dissolved organic compounds released into the overlying water during the feeding activities of the chironomids [11]. Similar observations were made during an experiment with Chironomus crassimanus larvae: Control sediment cores that were exposed to the same overlying water as the animal-inhabited cores showed increased $\mathrm{O}_{2}$ consumption rates (M. Koschorreck, UFZ Magdeburg, personal communication).

Identity and Distribution of Nitrifiers. In our investigation the presence of $C$. riparius larvae in some cases influenced the activity of nitrifiers, but never the abundance of $\mathrm{AOB}$ and $\mathrm{NOB}$ as quantified with FISH. Thus, $C$. riparius larvae did not efficiently decimate the nitrifying population at the sediment surface, nor did they significantly promote the growth of nitrifiers in the ventilation layer of the sediments. Since the observed activity changes were not density-regulated, they must have occurred, as detailed above, as a result of changes in the metabolic performance of the existing bacterial populations. In this context we want to stress that the vertical patterns of activity and abundance of nitrifiers do not necessarily match. Metabolically inactive cells may survive in both oxic and anoxic sediment layers for extended periods of time $[9,20,31]$. Despite starvation and other stress conditions (e.g., anoxia), nitrifiers maintain a relatively high ribosome content and are thus detectable with FISH, even when not actively nitrifying. Applying methods for the detection of single-cell activity may extend the meaning of FISH data in the future. For example, the cellular levels of precursor rRNA or transcribed intergenic spacer regions can be monitored and used for the determination of not only the size, but also the in situ activity of certain bacterial populations [21, 31]. Moreover, DNA-synthesizing cells can be specifically detected by the uptake of the halogenated thymidine analogue bromodeoxyuridine and consecutive FISH [24].

\section{Summary and Conclusions}

Depending on the sediment type, the inhabiting C. riparius larvae showed different burrowing and feeding activities. As a consequence, sedimentary nitrification was influenced differently: (i) In organic-poor sediment the net nitrification activity was reduced because of the intense, but evenly distributed larval grazing, while (ii) in organic-rich sediment the net nitrification activity remained rather unaffected in the space between animal burrows. In the latter case, total flux measurements revealed the burrows as additional sinks of $\mathrm{NO}_{3}^{-}$rather than sites of net nitrification. Extrapolated to benthic ecosystems the sediment type may thus be decisive in regulating the impact of $C$. riparius on nitrification. However, larval effects on nitrification were not strong enough to change the overall role of the investigated sediments as sources (organic-poor) or sinks (organic-rich) of $\mathrm{NO}_{3}^{-}$.

The results of this study stress the need for further work on the small scale until the complex interactions between sediment-dwelling animals and the microbial community can be comprehensively understood. For instance, microsensor measurements directly within the burrows and at the surface of larval feces could enhance our knowledge of local effects of bioturbation on microbial $\mathrm{N}$ conversions. Moreover, future studies should address the quantification of the metabolically active fraction of nitrifying and denitrifying bacteria with the molecular techniques of modern microbial ecology.

\section{Acknowledgments}

We thank Enrique Llobet-Brossa and Armin Gieseke for their advice and helpful comments regarding FISH in sediments. Gabi Eickert, Anja Eggers, and Ines Schröder are acknowledged for the construction of $\mathrm{O}_{2}$ microelectrodes. For critical comments on the paper we thank Rebecca Ludwig and Armin Gieseke. For statistical advice we are grateful to Werner Wosniok (University of Bremen). Financial support was provided by the German Research Foundation (STI202/1-2), and by the Max Planck Society, Germany.

\section{References}

1. Altmann, D, Stief, P, Amann, R, de Beer, D, Schramm, A (2003) In situ distribution and activity of nitrifying bacteria in freshwater sediment. Environ Microbiol 5: 798-803

2. Archer, D, Devol, A (1992) Benthic oxygen fluxes on the Washington Shelf and Slope: a comparison of in situ microelectrode and chamber flux measurements. Limnol Oceanogr 37: 614-629 
3. Bartoli, M, Nizzoli, D, Welsh, DT, Viaroli, P (2000) Short-term influence of recolonisation by the polycheate worm Nereis succinea on oxygen and nitrogen fluxes and denitrification: a microcosm simulation. Hydrobiologia 431: 165-174

4. Daims, H, Nielsen, JL, Nielsen, PH, Schleifer, KH, Wagner, M (2001) In situ characterization of Nitrospira-like nitrite oxidizing bacteria active in wastewater treatment plants. Appl Environ Microbiol 67: 5273-5284

5. de Beer, D, Stoodley, P (1999) Microbial Biofilms. In: Dworkin, M (Ed.) The Prokaryotes: An Evolving Electronic Resource for the Microbiological Community, Springer-Verlag, New York, Chapter 267

6. de Beer, D, Sweerts, JPRA (1989) Measurement of nitrate gradients with an ion-selective microelectrode. Anal Chim Acta 219: 351356

7. de Beer, D, van den Heuvel, JC (1988) Response of ammoniumselective microelectrodes based on the neutral carrier nonactin. Talanta 35: 728-730

8. DeLong, EF, Wickham, GS, Pace, N (1989) Phylogenetic stains: ribosomal RNA-based probes for the identification of single cells. Science 243: 1360-1363

9. Gieseke, A, Purkhold, U, Wagner, M, Amann, R, Schramm, A (2001) Community structure and activity dynamics of nitrifying bacteria in a phosphate-removing biofilm. Appl Environ Microbiol 67: $1351-1362$

10. Goedkoop, W, Gullberg, KR, Johnson, RK, Ahlgren, I (1997) Microbial response of freshwater benthic community to a simulated diatom sedimentation event: Interactive effects of benthic fauna. Microb Ecol 34: 131-143

11. Herbert, RA (1999) Nitrogen cycling in coastal marine ecosystems. FEMS Microbiol Rev 23: 563-590

12. Johnson, RK, Boström, B, van de Bund, W (1989) Interactions between Chironomus plumosus (L.) and the microbial community in surficial sediments of a shallow, eutrophic lake. Limnol Oceanogr 34: 992-1003

13. Kristensen, E, Jensen, MH, Andersen, TK (1985) The impact of polychaete (Nereis virens Sars) burrows on nitrification and nitrate reduction in estuarine sediments. J Exp Mar Biol Ecol 85: 75-91

14. Llobet-Brossa, E, Rossello-Mora, R, Amann, R (1998) Microbial community composition of Wadden Sea sediments as revealed by fluorescence in situ hybridization. Appl Environ Microbiol 64: 2691-2696

15. Manz, W, Amann, R, Ludwig, W, Wagner, M, Schleifer, K-H (1992) Phylogenetic oligodeoxynucleotide probes for the major subclass of proteobacteria: problems and solutions. Syst Appl Microbiol 15: 593-600

16. Matisoff, G, Fisher, JB, Matis, S (1985) Effects of benthic macroinvertebrates on the exchange of solutes between sediments and freshwater. Hydrobiologia 122: 19-33

17. Mayer, MS, Schaffner, L, Kemp, WM (1995) Nitrification potentials of benthic macrofaunal tubes and burrow walls: effects of sediment $\mathrm{NH}_{4}^{+}$and animal irrigation behavior. Mar Ecol Prog Ser 121: $157-169$

18. Mobarry, BK, Wagner, M, Urbain, V, Rittmann, BE, Stahl, DA (1996) Phylogenetic probes for analyzing abundance and spatial organization of nitrifying bacteria. Appl Environ Microbiol 62: $2156-2162$

19. Morgenroth, E, Obermayer, A, Arnold, E, Brühl, A, Wagner, M, Wilderer, PA (2000) Effect of long-term idle periods on the performance of sequencing batch reactors. Wat Sci Technol 41: 105113
20. Oerther, DB, Pernthaler, J, Schramm, A, Amann, R, Raskin, L (2000) Monitoring precursor $16 \mathrm{~S}$ rRNAs of Acinetobacter spp. in activated sludge wastewater treatment systems. Appl Environ Microbiol 66: 2154-2165

21. Pelegri, SP, Blackburn, TH (1994) Bioturbation effects of the amphipod Corophium volutator on microbial nitrogen transformations in marine sediments. Mar Biol 121: 253-258

22. Pelegri, SP, Blackburn, TH (1996) Nitrogen cycling in lake sediments bioturbated by Chironomus plumosus larvae, under different degrees of oxygenation. Hydrobiologia 325: 231-238

23. Pernthaler, A, Pernthaler, J, Schattenhofer, M, Amann, R (2002) Identification of DNA-synthesizing bacterial cells in coastal North Sea plankton. Appl Environ Microbiol 68: 5728-5736

24. Pernthaler, J, Glöckner, FO, Unterholzner, S, Alfreider, A, Psenner, R, Amann, R (1998) Seasonal community and population dynamics of pelagic bacteria and archaea in a high mountain lake. Appl Environ Microbiol 64: 4299-4306

25. Plante, CJ (2000) Role of bacterial exopolymeric capsules in protection from deposit-feeder digestion. Aquat Microb Ecol 21: 211219

26. Prosser, JI (1989) Autotrophic nitrification in bacteria. In: Rose, AH, Tempest, DW (Eds.) Advances in Microbial Physiology, vol. 30, Academic Press, New York, pp 125-181

27. Revsbech, NP (1989) An oxygen microsensor with a guard cathode. Limnol Oceanogr 34: 474-478

28. Rouf, MA, Rigney, MM (1993) Bacterial florae in larvae of the lake fly Chironomus plumosus. Appl Environ Microbiol 59: 1236-1241

29. Sakita, S, Kusuda, T (2000) Modeling and simulation with microsites on vertical concentration profiles in sediments of aquatic zones. Wat Sci Technol 42: 409-415

30. Schmid, M, Schmitz-Esser, S, Jetten, M, Wagner, M (2001) 16S$23 \mathrm{~S}$ rDNA intergenic spacer and $23 \mathrm{~S}$ rDNA of anaerobic ammonium-oxidizing bacteria: implications for phylogeny and in situ detection. Environ Microbiol 3: 450-459

31. Schramm, A, de Beer, D, Gieseke, A, Amann, R (2000) Microenvironments and distribution of nitrifying bacteria in a membranebound biofilm. Environ Microbiol 2: 680-686

32. Schramm, A, Larsen, LH, Revsbech, NP, Amann, R (1997) Structure and function of nitrifying biofilm as determined by microelectrodes and fluorescent oligonucleotide probes. Wat Sci Technol 36: 263-270

33. Stief, P, de Beer, D (2002) Bioturbation effects of Chironomus riparius on the benthic $\mathrm{N}$-cycle as measured using microsensors and microbiological assays. Aquat Microb Ecol 27: 175-185

34. Stief, P, de Beer, D, Neumann, D (2002) Small-scale distribution of interstitial nitrite in freshwater sediment microcosms: the role of nitrate and oxygen availability and sediment permeability. Microb Ecol 43: 367-378

35. Svensson, JM (1998) Emission of $\mathrm{N}_{2} \mathrm{O}$, nitrification and denitrification in a eutrophic lake sediment bioturbated by Chironomus plumosus. Aquat Microb Ecol 14: 289-299

36. Svensson, JM (1997) Influence of Chironomus plumosus larvae on ammonium flux and denitrification (measured by the acetylene blockage- and the isotope pairing-technique) in eutrophic lake sediment. Hydrobiologia 346: 157-168

37. van de Bund, W, Goedkoop, W, Johnson, RK (1994) Effects of deposit feeder activity on bacterial production and abundance in profundal lake sediment. J N Am Benthol Soc 13: 532-539

38. Wagner, M, Rath, G, Koops, HP, Flood, J, Amann, R (1996) In situ analysis of nitrifying bacteria in sewage treatment plants. Wat Sci Technol 34: 237-244 